\title{
Articles
}

\section{Social workers' perceptions on clients' service needs and social work practices during the COVID-19 pandemic}

by

Merita Mesiäislehto

Senior Researcher, PhD

Finnish Institute for Health and Welfare

Finland

E-mail: merita.mesiaislehto@thl.fi

Minna Kivipelto, PhD

Research Manager

Finnish Institute for Health and Welfare

Finland

E-mail: minna.kivipelto@thl.fi

Heikki Hiilamo

Research Professor

Finnish Institute for Health and Welfare

Finland

E-mail: heikki.hiilamo@thl.fi

Keywords:

social work, Covid-19, access to services

DOI: https://doi.org/10.31265/jcsw.v16.i2.396

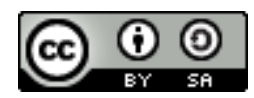

This work is licensed under a Creative Commons Attribution-ShareAlike 4.0 International License. 


\begin{abstract}
Ever since the start of the COVID-19 pandemic, the specialized health-care resources have been the main focus of political attention in any country. However, the pandemic and subsequent lockdowns have also had a major impact on social services. The pandemic increased service needs among those who were already adult social work clients before the pandemic; it also created needs among new groups of clients, while the operating environment for service provision changed dramatically.
\end{abstract}

In our study, we examine social workers' perceptions on: 1) how well social services were able to respond to clients' needs during the pandemic; and 2) examine practices in adult social work that were used and developed during the outbreak of the pandemic. For the analysis, we use national survey data obtained from social workers in the Social Barometer survey collected in May $2020(n=496)$ and in January $2021(n=412)$. The findings show that according to social workers, during the first year of the pandemic social work in Finland succeeded in responding to clients' rather clear and concrete problems, such as difficulties in applying for social benefits and a lack of housing, while more complicated problems, such as unmanageable debts, loneliness and mental health problems, were not adequately responded to. At the same time, social workers assessed that people suffering from these problems were the most affected by the COVID-19 pandemic.

Keywords: social work, Covid-19, access to services 


\section{Introduction}

Ever since the start of the COVID-19 pandemic, the specialized health-care resources have been the main focus of political attention in any country. However, the pandemic and subsequent lockdowns have also had a major impact on social services. The pandemic increased service needs among those who were already clients before the pandemic, and has created needs among new groups of clients, while the operating environment for service provision changed dramatically. In many countries, social services were closed or remained open with limited access, and community and group activities were discontinued.

In this study, we examine the situation of adult social work and its clients during the COVID-19 pandemic in Finland in 2020. In terms of social vulnerabilities Finland was perhaps better prepared than many other countries. Finland is characterized by the Nordic welfare state model, known for low levels of poverty and high levels of wellbeing, as well as its universalistic and all-encompassing approach to welfare. Unlike many other countries around the world, Finland did not go under total lockdown at any point of the pandemic. Nevertheless, the restrictive measures related to social distancing during the first wave of COVID-19 created serious challenges for public services, including social work, to provide services for all citizens in need of support in a situation where face-to-face services were unavailable, or strictly limited.

Subsequently, Finland has gradually transferred to a "hybrid strategy", referring to a move from extensive restrictive measures to enhanced management of the epidemic (Tiirinki et al., 2020).

The massive lockdown during the months of March and April 2020 decreased the number of new infections, and dampened economic activity in Finland.

Unemployment and layoffs rapidly increased. The number of applications made to the Social Insurance Institution (Kela) for basic unemployment benefits doubled, and applications for housing allowances increased by more than one-third (Kangas 2020). A previous report on the social work response to COVID-19 highlighted the role of digital tools (remote and digital meetings with clients), disruptions of some non-urgent social services (including voluntary sector services, such as daily groups for older people, peer support groups for people with mental health problems), loss of contact with basic services (such as schools, school nurses, mental health services, 
homeless shelters) and an accumulation of service debt which will become visible after the pandemic (Tiitinen et al., 2020). In Finland, the social assistance spells among young adults were longer in 2020 than in previous years, with the prevalence of social assistance receipt particularly increased among young women (Jokela et al., forthcoming). In addition, COVID-19 restrictions in Finland seem to have had a negative impact on young people with the weakest social resources, who are shown to suffer from loneliness more often than others (Haikkola \& Kauppinen, 2020).

Several studies have measured the economic impacts of the COVID-19 pandemic on families in different countries (e.g. Power, 2020; Martin et al., 2020), whereas some have also focused on the ability of social security systems to respond to families' and individuals' income losses (e.g. Dutta \& Fischer, 2021; Jamaluddin et al., 2021). However, knowledge on the use of services, particularly for the most vulnerable groups of population, has been less studied.

This study aims to fill the gap by concentrating on social workers' perceptions on: 1) how well social services were able to respond to clients' needs during the pandemic; and 2) the practices in adult social work that were used and developed during the first year of the pandemic. Social workers' views on their clients' situation and the functioning of social services provides valuable information on how well the welfare state can take care of its citizens who are in the most need of support in times of crisis. For the analysis, we use national survey data obtained from social workers in the Social Barometer survey collected in May $2020(n=496)$ and January 2021 $(n=412)$.

\section{Adult social work in Finland}

Finland has a long tradition of strong egalitarian approaches. Finland is often promoted as a welfare state with qualities such as non-discrimination and equality, services in health, well-being and education financed by means of tax revenue, high social mobility and an active civil society (Prime Minister's Office, 2019.) However, Finland does have a severe social division affecting people in many ways, including poverty and a prolonged need for social assistance (Grekula et al., 2020). Inequality is also reflected in the differences in health and social inclusion between population 
groups, and in the percentage of young people who are not in education, employment or training (NEET).

This study focuses on adult social work, which covers clients among the working age population. In Finland, adult social work is used as a broad category for clients over 16 years of age. Adult social work is generally divided into two target groups, but age categories vary between municipalities. Young adult social work clients are typically between 16 and 29 years of age. Clients with children usually visit family services, and not adult social work, despite their age.

Adult social work services are organized at the local level, and are used by around $5 \%$ of the adult population in Finland (Finsote, 2018). The primary client groups in adult social work are people who suffer economic problems and difficulties in life management. Many clients also have mental health problems, and a weak and limited work ability (Jokela \& Kivipelto, 2021; Koponen 2020, pp. 103-104). Most clients are long-term unemployed or NEET youth, i.e., young people who are outside the labour market or without training (Blomgren \& Kivipelto, 2012; Holte et al., 2019). Due to their complex life situations, clients in adult social work are generally in situations with reduced employment opportunities. Social work is a multidisciplinary profession, in which processes must be client-driven and based on the clients' own goals (Karjalainen et al., 2019). Most common methods in Finnish social work are supportive discussions with clients, social assistance and delivering suitable services for clients. Even so, social work methods are not clear-cut, and different methodological interventions are mixed (Kivipelto et al., 2013, pp. 25-26.).

Since most social work clients are in need of financial support, social assistance plays a key role in adult social work. Basic social assistance can be provided to individuals or families living or residing in Finland, whose income and assets do not cover their essential daily needs, such as food and medicine (Social Insurance Institution of Finland [KELA], 2020). One-third of social assistance clients are in need of social services (Jokela \& Kivipelto, 2021). Basic social assistance, the last-tier means-tested minimum income benefit, is centralized and administered by the Social Insurance Institution, Kela. Municipal social services are only responsible for the discretionary elements of social assistance, and preventive and supplementary social 
assistance, whose expenditure corresponds to approximately $10 \%$ of total social assistance costs.

\section{Responding to service needs of vulnerable groups during the COVID-19 pandemic}

Challenges in accessing services during the pandemic

As the pandemic continues, the social and economic inequalities related to its consequences become more visible. A number of studies find that the economic consequences of the pandemic have been most severe among young people and low-income earners (Adams-Prassl et al., 2020; Alstadsæter et al., 2020; Lee et al., 2020), and particularly female and migrant workers were more likely to lose their jobs during the pandemic (Oreffice \& Quintana-Domeque, 2020; Platt \& Warwick, 2020). In addition to job and income losses, the COVID-19 crisis has increased the psychological burden of individuals, who are attempting to cope with social distancing measures and increased care responsibilities due to the closure of schools and kindergartens and other public spaces (Kestilä et al., 2021; Salin et al., 2020). Crises give also rise to new types of vulnerabilities (Napier, 2020).

The rapid increase of remote services due to the restrictive measures have created a discussion on public institutions' ability to deliver services during the crisis, and how well different groups of population have access to them. The digitalization of services was already a widely debated issue in social work prior to the pandemic. In many European countries, the recent trend has been to digitalize social services, which has created challenges for social work practices, as face-to-face services are reduced and clients' own responsibility and online practices take on a greater role (Schou \& Pors, 2018). Not all citizens are equal in terms of access to electronic devices, or the skills required to navigate computerized spaces optimally (Beaunoyer et al. 2020; Tuikka, 2019; Van Winkle et al., 2017). The shift towards 'e-social work' (see Devlieghere \& Moore, 2018; Peláez et al., 2018) is said to particularly affect the most vulnerable groups of social assistance recipients, who apart from benefits need social services and individual counselling. On the other hand, digitalization is viewed as a positive development, as it may help to get in contact with clients residing in more remote areas. (Misha et al., 2020). 
Social services play a crucial role in economic crises, insofar as supporting the most vulnerable groups of the society. However, according to lain Ferguson (2020), social work is being blamed as 'invisible' in the current crisis. He argues that the limited role of social work is not the fault of individual social workers, or even of individual managers. Instead, it reflects the dominance of the market-driven ideology that emerged in the 1990s, sometimes called New Public Management (NPM), or managerialism. Ferguson suggests that this has resulted in an increased bureaucracy, with social workers often spending more time in front of computers than with their clients (see also Christensen \& Laegreid, 2007). A similar trend has been described to happen in Finland, where publicly funded services have been opened up to be provided by private and third-sector actors, as municipalities have gained more autonomy in deciding how to provide their services, with the increased bureaucracy having led to social workers doing more and more administration and documentation work, instead of direct face-to-face interaction with clients (Marjanen et al., 2018).

In any case, social distancing measures are particularly affecting the livelihoods of those who cannot work remotely, and thus either run the risk of exposure when going to work or lose their income if they stay at home (see Patel et al., 2020). For many households, the possibilities to choose between work and staying at home are small if they do not even have savings to cover one month's income. The potential of buffering incomes within household also depends on the spouse's income (Platt \& Warwick, 2020). The consequences of the pandemic not only affect adults, but are also reflected in children's well-being. A review of 12 studies concerning the effect of the pandemic on vulnerable children showed increased levels of distress and problems in accessing necessary services (Nelimarkka et al., 2021). In addition, policy reports indicate an increase in domestic violence during the pandemic.

Policies to address the service system during the COVID-19 pandemic in Finland The comprehensive nature of the Finnish social protection system was reflected in the fact that not many changes were made to the existing benefits schemes as a result of the COVID-19 pandemic. The existing system already covered risks actualized by the COVID-19 crisis, such as loss of income due to a furlough or in the case of an infectious disease, and unemployment and sickness. Temporary changes 
were made to unemployment benefits available to employees and self-employed persons, including increases in benefit levels and looser eligibility criteria. For individuals who were laid off temporarily, it became possible to receive unemployment benefits while studying (Social Insurance Institution of Finland, 2020a.).

A temporary compensation due to an epidemic outbreak for basic social assistance clients was introduced for four months (September to December 2020) to support the most vulnerable persons and families who incurred extra costs as a result of the restrictions imposed due to the coronavirus epidemic. The temporary compensation (75 Euro per person) was granted to persons who received basic social assistance for part of the time, or for the entire time that the restrictions due to the coronavirus epidemic have been in force (Social Insurance Institution of Finland, 2020b).

In addition, the Ministry of Social affairs and Health gave instructions to the authorities providing social assistance to ease the process of applying for the assistance. These included simplifying means-testing during the first months of the crisis, and removing sanctioning (Social Insurance Institution of Finland, 2020a). The instructions were still followed during the autumn of 2020, but in 2021 most of the old practices, including sanctioning, were in use again.

A study based on the diary entries of 33 Finnish frontline social workers between March and May 2020 showed that although social workers were unprepared for the situation, they adapted to it quickly, and adopted adequate ways of working (Harrikari et al., 2021). A report by Tiitinen et al. (2020), describing the situation as of July 2020 in Finland, noted that social workers were worried about older people in general, and those in care homes in particular. According to the report, the daily groups for older people and other daily services had been closed; consequently, the relatives caring for them had no opportunities to rest and/or take time off. A report by Tiitinen et al. (2020) pointed out that the social workers experienced obstacles in approaching and supporting communities and clients/service users, resulting from the fact that during the lockdown the basic services such as schools, school nurses, mental health services and homeless shelters were closed. The closure of services also 
complicated the information flow to social services regarding the people in need of help.

\section{Data and methods}

In this research, the impacts of the COVID-19 pandemic on social services are examined from the perspective of social workers. There are several reasons for this. First, surveying professionals allows us to obtain information on the situation of social services in Finland during the COVID-19 crisis shortly after it started, which also served policymakers and other actors working in the field. Social work clients' contact information in municipalities is confidential; thus, a survey on social work clients is time consuming, and requires additional resources that were not possible to acquire within the timeline of this study. In previous studies, apart from recruiting client respondents through social work, service users' perspective has also been studied via essay competitions (Kuuskoski, 2020; Kulmala, 2006) and food aid (Linnanvirta et al., 2020; Ohisalo \& Saari, 2014). It should be considered that no research method is free from the use of power. For instance, all vulnerable clients are not readers of newspapers; they do not all use social media or are not seeking food aid. This leads to the fact that respondents or interviewees are always selected, in one way or another. However, we are aware that our research design is limited in the sense that it does not allow to analyse social work clients' position from their own perspective. In addition, when analysing the results, we are conscious of the fact that social workers' views are transmitted by their own experiences, contexts and cultural and social backgrounds (Healy, 2001). It is evident that there are un-symmetric power relations between professionals and service users that affect respondents' opinions and interpretations (Lipsky, 2010). Nevertheless, it is not known whether social workers concerns are built upon their observations of social work practice, or if they reflect more the general concerns on how the pandemic affects the most vulnerable groups of the population.

For the analysis we use Social Barometer, a national survey collected in May 2020 $(\mathrm{N}=776)$ and January $2021(\mathrm{~N}=1241)$. Social Barometer is an annual survey managed by SOSTE (Finnish Federation for Social Affairs and Health), which has been collected since 1991 from public welfare institutions, such as employment agencies, social services and the Social Insurance Institution of Finland. The 
respondents include both managers and street-level workers. The survey covers topics related to the well-being of citizens, the functioning of the health and welfare services and the position of the most vulnerable citizens in welfare services. For the purpose of this study, we focus on social workers' responses ( $n=496$ in 2020 and $n=412$ in 2021) that were collected through municipalities and local government joint services areas. They forwarded the questionnaire to social workers working in adult social work in their area, who then replied to the questionnaire online. In the first survey, the respondents were asked to reflect on the situation during the spring of 2020, while in the next round they were asked to reflect on the situation during a period from September to December 2020. The survey includes both structured and open-ended questions. In this study, we primarily use the responses of the structured questions. Some of the structured questions include an option for the respondent to specify their response with their own words, and we use these open-ended responses to complement our analysis. Unfortunately, the questions were not included in the rounds predating the pandemic, which is why we cannot make a comparison to previous years.

First, we examine social workers' views on the ability of social work to respond to clients' needs during the pandemic by studying what kind of challenges they found that the clients faced, and how well social work in their opinion was able to respond to these challenges. This was done by utilizing the following questions:

In your opinion, what are the main challenges among clients during the COVID-19 pandemic in September/December 2020? You may choose up to three main challenges.

In your opinion, to what degree is social work able to respond to the needs of the following groups (scale 1-5).

Moreover, the questions included an option of "other", in which the respondent could provide an answer in the form of an open response.

Second, social workers' experiences on the impact of COVID-19 on social work practices are analysed using the following question: 
Which work practices did you improve/add in September/December compared to the spring in order to help the clients?

Unfortunately, there is no information about the number of social workers to whom the questionnaire was sent, which is why it is not possible to calculate the response rate. However, according to the documentation of the survey, responses were received from $64 \%$ of the total number of municipalities and local government joint service areas in May 2020. The corresponding figure in January was $53 \%$. All in all, it may be concluded that the responses represent different types and sizes of municipalities from all regions of the country (Sosiaalibarometri, 2021b).

The background characteristics of the respondents are presented in Table 1. The majority of the respondents in both survey rounds were social workers, followed by social counsellors, social work managers and other counsellors, such as housing advisors or rehabilitation counsellors. Most of the respondents hold a Master's degree in social work. The education level among the respondents in May was a bit higher than in January (share of licenced social workers was $75 \%$ vs. $65 \%$ ). In both data sets, the proportion of workers with over five years of work experience was $36 \%$. 
Table 1: Title, education and work experience of the respondents, \%

\begin{tabular}{|c|c|c|}
\hline & $\begin{array}{l}2020 \\
(n=496)\end{array}$ & $\begin{array}{l}2021 \\
(n=412)\end{array}$ \\
\hline \multicolumn{3}{|l|}{ Title } \\
\hline Social worker & 68 & 59 \\
\hline Social work manager & 11 & 16 \\
\hline Social counsellor & 13 & 19 \\
\hline Other counsellor (e.g. housing/rehabilitation adviser) & 8 & 6 \\
\hline Total & 100 & 100 \\
\hline \multicolumn{3}{|l|}{ Highest degree obtained } \\
\hline Licenced social worker (Master's degree) & 75 & 65 \\
\hline Other university degree & 7 & 6 \\
\hline $\begin{array}{l}\text { Bachelor/Master of Social Services (University of Applied } \\
\text { Sciences) }\end{array}$ & 15 & 23 \\
\hline $\begin{array}{l}\text { Other Bachelor/Master degree from University of Applied } \\
\text { Sciences }\end{array}$ & - & 4 \\
\hline Secondary education & - & 1 \\
\hline Other degree(s) & 3 & 1 \\
\hline Total & 100 & 100 \\
\hline \multicolumn{3}{|l|}{ Work experience in current job in years } \\
\hline Less than a year & 23 & 16 \\
\hline $1-5$ years & 41 & 48 \\
\hline 510 years & 17 & 16 \\
\hline $10-20$ & 14 & 13 \\
\hline Over 20 years & 5 & 7 \\
\hline Total & 100 & 100 \\
\hline
\end{tabular}

\section{Results}

Responding to clients' needs in social work

During the first lockdown period in spring 2020, the restrictions caused by the pandemic led to a general concern about the well-being of the most vulnerable groups in society. This was also the experience of the social workers who responded to the survey: $45 \%$ mentioned loneliness as social work clients' greatest problems during that time (Figure 1), followed by challenges related to life management and financial issues. Once most of the restrictions were lifted in the summer of 2020, most of the social work practices resumed. At the end of 2020 , social workers were 
mostly worried about clients' mental health; as many as $48 \%$ of workers mentioned this as one of the primary challenges among their clients. More importantly, clients' mental health was mentioned as a main challenge approximately four times more frequently in fall 2020 compared to spring 2020. In addition, concerns for securing housing and problems associated with substance abuse were more pronounced in the fall of 2020.

In both surveys, social workers were worried about clients' financial problems and debts. Altogether, $42 \%$ of workers mentioned financial problems and debts as being among the key challenges among their clients in the spring. The situation did not change for the better in the fall, when $42 \%$ of social workers mentioned this as one of the biggest problems among their clients. Also, clients' life management and problems in everyday life, as well as problems with alcohol, were mentioned. The limited access to services, particularly among clients with multiple problems, raised concerns among social workers, who described the situation in open-ended questions as follows:

Those who have problems with alcohol or mental health are often people with a low income who need more help. Has there been enough possibilities to support them - I doubt that? Services brought to [clients'] homes have been transformed to remote services, which has probably increased financial difficulties. The support provided by phone does not replace personal contact.

Unemployed job seekers needed help with benefit applications, a personal contact. They do not get enough guidance and advice online or over the phone. 


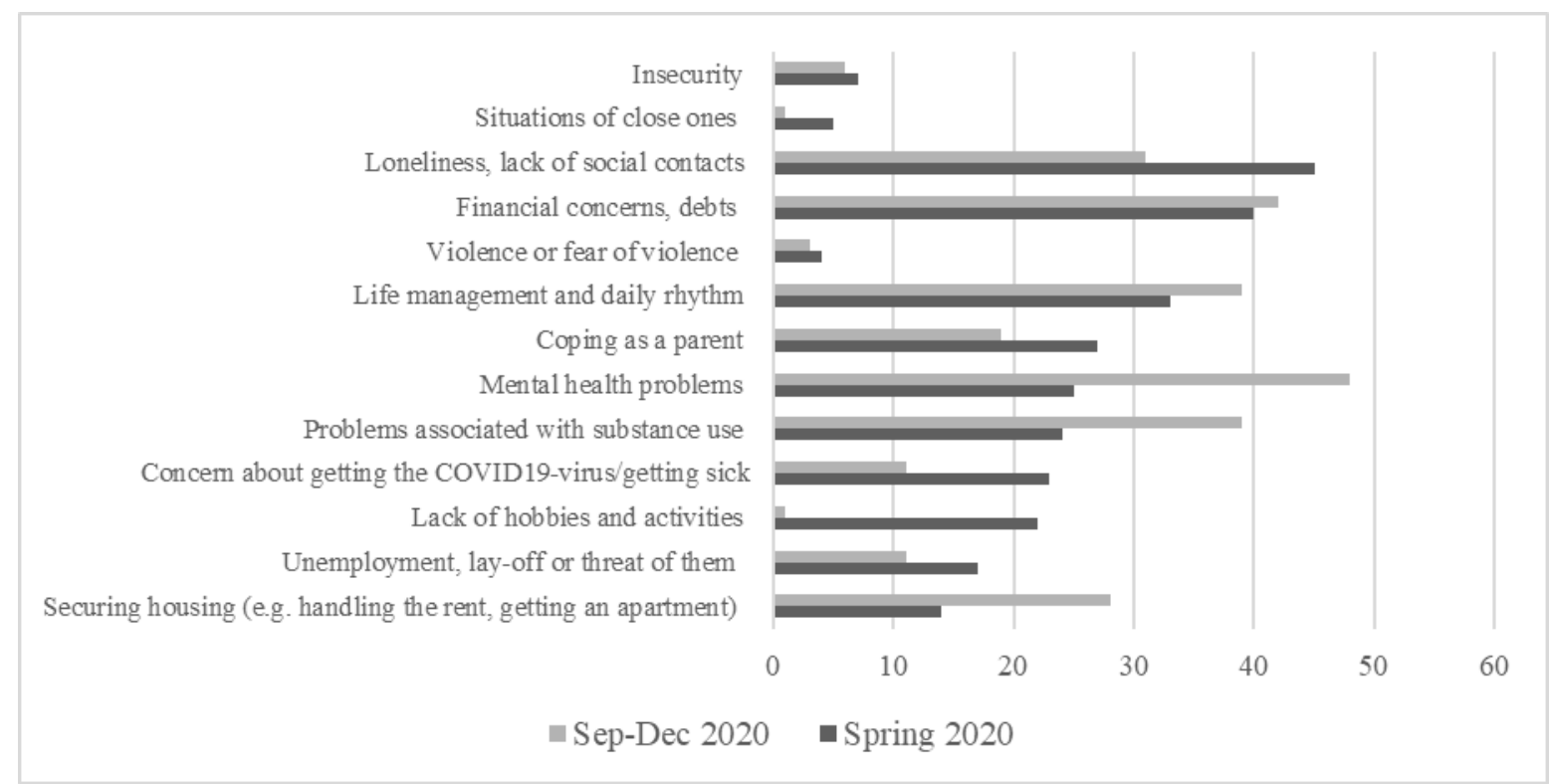

Figure 1: Clients' main challenges according to social workers in March-May 2020 and September-December 2020, \%, $(n=377-440)$

In the spring, nearly half the respondents viewed the clients' lack of social contacts as a huge challenge; nonetheless, at the end of 2020 the issue was reported by only one-third of the respondents. Concerns about getting the COVID19-virus, coping as a parent, a lack of hobbies and activities and the threat of unemployment and lay-offs decreased from spring 2020 to autumn 2020. Comparing the results from the spring and fall of 2020 shows that the COVID-19 pandemic seems to have mostly affected social work clients' lives in terms of financial situation, life management and mental health problems. The results point to an aggravation of problems in these areas.

In September to December 2020, social workers felt that they were able to respond well to concrete service needs, such as food aid, benefits or subsidies or clients with general life management problems (Figure 2). The notion is supported by evidence from other sources. In particular, social assistance has been flexible, and the number of clients has not increased drastically during the epidemic (Jokela et al., forthcoming). According to other studies, the situation of food aid clients was worse in larger than in smaller municipalities, but generally, the needs were well met (Alppivuori, 2021; Laihiala \& Nick, 2020). Other issues that were responded to fairly well according to social workers included families' needs related to preventive or rehabilitative child welfare and shopping assistance. 
Evidently, social workers were not able to respond to all client groups' service needs satisfyingly during the COVID-19 pandemic. According to the results, social workers felt they were least capable to respond to service needs of clients waiting for access to mental health services, clients who had a weak functional capacity and those lacking the ability to use remote or digital services. The situation was not better for the lonely or people living in isolation due to the COVID19. Also, service needs of substance and drug users, as well as the indebted, were met weakly or fairly weakly (see also Kestilä et al., 2021). The analysis of the results by educational background and length of work experience (not shown here) indicates that social counsellors tended to be more critical in how well the clients' needs were responded to compared to social workers. No significant differences were found between workers with shorter and those with a longer work experience:

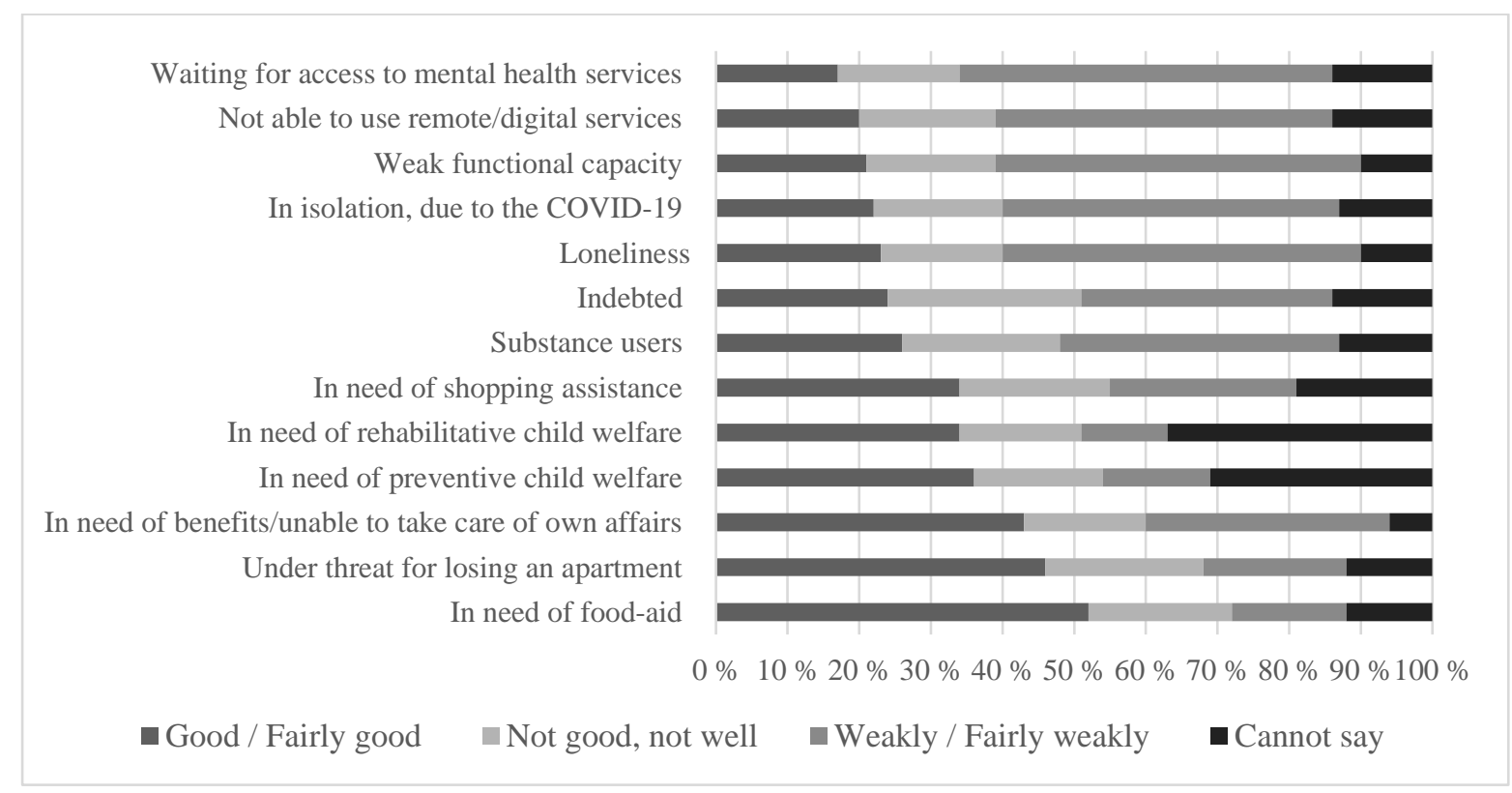

Figure 2: Responding to the service-needs of different client groups, according to the social workers, September-December 2020 (\%) (N=379).

The respondents were asked in a separate question about the ability of the Social Insurance Institution to respond to the service needs of clients in need of basic social assistance during the COVID-19 pandemic. Approximately $40 \%$ of social workers viewed the response to service needs as positive, while roughly one-fifth rated the response to service needs as negative. The open-ended responses of social workers highlighted the problems faced by the most vulnerable groups who do not possess the skills to use digital devices, or do not have access to them or those with limited 
language skills. These population groups include the elderly, migrants with limited language skills and persons with mental problems:

[Problems most severe] among those who have nothing. Especially since they cannot take care of their matters online. This client group will always need face-to-face service.

Clients do not have access to Kela [Social Insurance Institution of Finland]; it is difficult to understand advice on the phone. It is especially difficult for immigrants who do not speak Finnish.

The social workers also reported that public services are increasingly replaced through services provided by faith-based organizations and NGOs. Their role was estimated to have grown considerably during the pandemic. Much of the nonstatutory support focused on offering practical help, such as food assistance, as well as providing counselling and psychological and social support.

In comparing social workers' assessment of those mostly affected by the crisis, and the success in responding to the service s of different client groups, it appears that social work failed to meet the service needs among those who have suffered the most from the crisis. These groups include people with financial needs and debts, people suffering from loneliness and people with mental health problems (see also Knop, 2021; Kivipelto et al., 2020). The survey results highlight that during the COVID-19 crisis the Finnish welfare system was clearly able to meet relatively targeted needs, such as the need for food aid, housing or social benefits. On the other hand, for those with more complex issues, for instance, life management or mental health problems, help has often not been as easily accessible. It therefore seems that the Finnish social security system is failing at what should be the core of social work: helping those most in need.

\section{Social work practices during the COVID19-pandemic}

Before the COVID19 pandemic, on-site and outreach work were not widely used in Finland. Resources and organizational practices were often cited as reasons for not using them, and instead, social workers mostly met their clients at social services (Author, 2016). During the pandemic, a change in practices became imminent when face-to-face interaction had to be discontinued. In spring 2020, respondents reported that clients were met during outdoor activities and walks. According to the respondents, home visits and outreach work were done more than usual. In spring 
2020, social workers felt that the development of new working practices was very positive. The need for changes brought by the pandemic introduced a view that work methods could, and had to be changed, in order to correspond with the circumstances. In a way, the situation empowered social workers, and gave them a mandate to work differently.

In fall $2020,66 \%$ of social workers reported that contacting the clients by phone had increased (a lot or quite a lot) from spring 2020 to autumn 2020 (Figure 3). Almost half of the respondents reported that contacting clients by video applications, such as Teams or WhatsApp, had increased a lot or quite a lot. Use of preventive or supportive social assistance increased, as well as helping the clients with applying for basic social assistance. However, the response to the new practices varied among the clients as one of the respondents described:

Some do not have the equipment or skills. Some do not find remote connections appropriate for several reasons. Building trust requires more when you are trying to do so remotely. On the other hand, some are able to interact better than face-to-face.

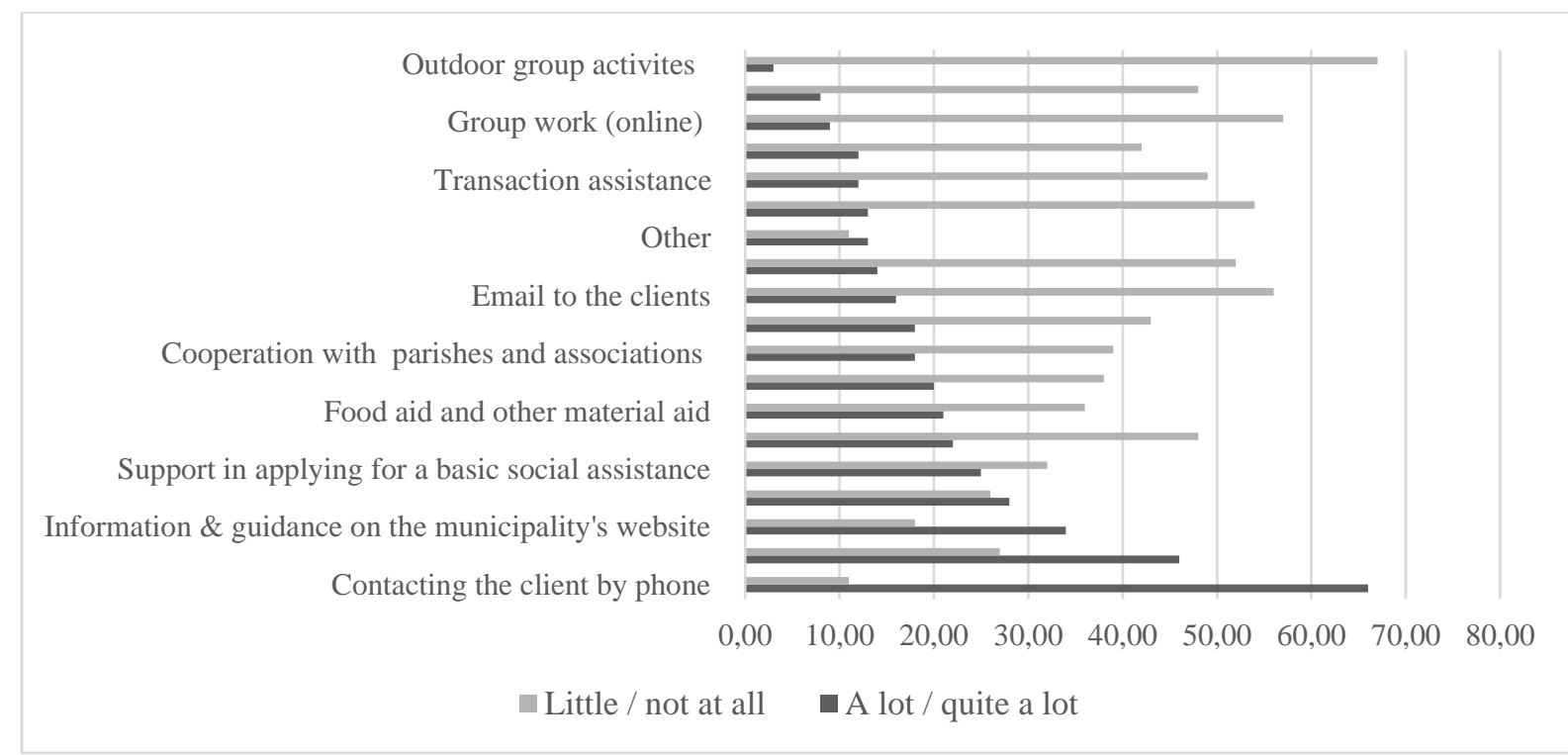

Figure 3: Social workers' perceptions on which social work practices were more used in September-December, compared to spring 2020, \%, $(n=372)$

While practices for remote services were developed quickly, social workers did not report any increase in contacting clients outside the office between spring 2020 and autumn 2020. For instance, only $13 \%$ of social workers brought up that outdoor meetings with clients increased significantly since the spring. In addition, outreach 
work, dismounted social work and outdoor group activities increased only slightly compared to spring.

Interestingly, a comparison of the results between the different professions and work histories (not shown here) suggests that there was some variance in using different methods among different groups of social workers: Generally, it may be said that those with a shorter work experience (less than 5 years) tended to increase the use of different work methods as the pandemic continued, compared to those with a longer work experience. Moreover, social counsellors reported an increase in the use of different methods more frequently than social workers. However, we do not know whether the latter is because they used fewer methods prior to the pandemic compared to social workers and the pandemic "enriched" their work methods, or whether they were more active in adopting other methods compared to social workers.

\section{Discussion}

Aligning with earlier research (e.g. Harrikari et al., 2021), we show that from the perspective of social workers, social work in Finland responded quickly to difficult problems and situations risen from the changing needs of clients. The results of this study suggest that social work succeeded in responding to clients' needs in case they were quite concrete or clearly defined, such as applying for social benefits or a lack of housing. Yet, social workers felt that more complicated problems, such as clients' financial situation and unmanageable debts, loneliness and mental health problems, were not adequately responded to. At the same time, social workers assessed that people suffering from these problems were the most affected by the COVID-19 pandemic (see also Lavalette et al., 2020).

The COVID-19 crisis acted as a "stress test" for the Finnish welfare state (Kangas, 2020). The preliminary result of the stress test was that the Finnish social security system performed well in buffering the negative economic effects of the pandemic for the general population (Greve et al., 2020; Jokela et al., 2021), although marginalized groups have been disproportionally affected by the crises. This is most visible among social work clients. There are several explanations for this worrisome development. First, as illustrated above, in Finland, as in many other countries, social 
work methods were significantly affected by the lockdown measures. Self-directed digital services were strongly introduced in social work and health care. While the digital services seem to have worked well for some clients, some of the most vulnerable people slipped through the safety net, as they were not able to use the remote and digital services offered.

Second, the clients had to struggle, and to be patient, while waiting for access to services, especially for mental health services. In Finland, there is no guarantee for a personal meeting with a social worker. In basic mental health services, records without meeting a client increased sharply at the end of 2020 (THL, Avohilmo). In December 2020, an average of $30 \%$ of adult psychiatry visits took place as remote visits (Suvisaari et al., 2021). As noted, a lack of personal contacts and face-to-face meetings caused hardship for those who suffered mental health problems. The new social work methods adopted in 2020 will therefore also be useful after the epidemic.

The results of this study showed that social work failed to meet the service needs among those who have suffered the most from the crisis. Community and group activities were discontinued, which weakened social work clients' agency. Previous research has demonstrated that access to social services depends on the client's own activity, which might be weak (Blomgren et al., 2016). Borrowing Amartya Sen's (2001) phrasing, this increased unfreedom left vulnerable persons with little choices and little opportunities for exercising their reasoned agency during the COVID-19 crisis. As proposed by the European Social Services (2021), public social services play a vital role in the recovery from the COVID-19 pandemic through supporting the employment, health and social inclusion of the most vulnerable in local communities across Europe. Hence, more transparent, expedient and easily accessible social services and activities are needed. Gaining and maintaining clients' trust is also vital for the success of these services. It is also worth considering whether it is appropriate that legislated public services are replaced through services provided through NGOs.

Surveying social workers during the first year of the pandemic offered an opportunity to quickly collect information on the changes in clients' needs and new ways to respond to them. Unfortunately, we were not able to collect data from the same individuals, so we cannot therefore study changes in perceptions on the individual 
level. As for the results concerning the service needs of the clients, it is necessary to note that we had no information on how the clients themselves experienced the situation. It is possible that social work clients have encountered problems and experienced service needs which have not been recognized by the social workers. In interpreting our results, it is also important to acknowledge that they reflect the situation in 2020. The total social, mental and economic costs of COVID-19 in Finland are still unknown. 


\section{References}

Adams-Prassl, A., Boneva, T., Golin, M. \& Rauh, C. (2020). Inequality in the impact of the coronavirus shock: Evidence from real time surveys. Journal of Public Economics 189. https://doi.org/10.1016/j.jpubeco.2020.104245

Alppivuori, K. (2021). Mitä kertovat ruoka-apua hakevat inmiset. Espoolainen ruokaapu, avun tarve ja palvelukokemuksetruoka-avun hakijoiden näkökulmasta. Espoon kaupunki. https://www.espoo.fi/download/noname/\%7BD45A3321 914A-4933-A24C-731ADC4C8964\%7D/138181

Alstadsæter, A., Bratsberg, B., Eielsen, G., Kopczuk, W., Markussen, S., Raaum, O. \& Røed, K. (2020). The First Weeks of the Coronavirus Crisis: Who Got Hit, When and Why? Evidence from Norway. NBER Working Paper No. 27131. https://doi.org/10.3386/w27131

Blomgren, S. \& Kivipelto, M. (2012). Valtaistus: Valtakunnallinen aikuissosiaalityön kartoitus. Helsinki: Finnish Institute for Health and Welfare.

Blomgren, S., Karjalainen, J., Karjalainen, P., Kivipelto, M., Saikkonen, P. \& Saikku, P. (Eds.). (2016). Sosiaalityö, palvelut ja etuudet muutoksessa. Raportti 4/2016. Helsinki: Terveyden ja hyvinvoinnin laitos. https://www.julkari.fi/handle/10024/130515

Beaunoyer, E., Dupéré, S. \& Guitton, M. J. (2020). COVID-19 and digital inequalities: Reciprocal impacts and mitigation strategies. Computers in Human Behavior, 11, 1-9. https://doi.org/10.1016/j.chb.2020.106424

Christensen, T. \& Laegreid, P. (2007). Transcending New Public management: The Transformation of Public Sector Reforms. Ashgate.

Crawford, C. A. (2021). Studying social workers' roles in natural disasters during a global pandemic: What can we learn? Qualitative Social Work, 20(1-2), 456462. https://doi.org/10.1177/1473325020973449

Devlieghere, J. \& Roose, R. (2018). Electronic Information Systems: In search of responsive social work. Journal of Social Work, 18(6), 650-665. https://doi.org/10.1177/1468017318757296

Dutta, A. \& Fischer, H. W. (2021). The local governance of COVID-19: Disease prevention and social security in rural India. World Development, 138, 1-11. https://doi.org/10.1016/j.worlddev.2020.105234

European Social Network (2021). Investing in Social Services, Investing in Europe. Social Services Essential for Europe's Recovery. https://www.esn- 
eu.org/sites/default/files/2020-

11/ESN_European\%20Semester\%202021_Interactive_spread_compressed.pdf Ferguson, I. (2020). Neoliberal social work and COVID-19. In M. Lavalette, V.

loakimidis \& I. Ferguson (Ed.), Social Work and the COVID- 19 Pandemic International Insights. Policy Press. https://doi.org/10.2307/j.ctv1850gc4.8 Finnish Institute for Health and Welfare (2020). Far-reaching impacts of the COVID19 epidemic on people's well-being and social and health care services. https://thl.fi/en/web/thlfi-en/-/far-reaching-impacts-of-the-covid-19-epidemic-onpeople-s-well-being-and-social-and-health-care-services

Grekula, E. M., Järvinen, A. \& Saarinen, E. (Ed.). (2020). Poverty Watch. Poverty Watch Report Finland 2020. EAPN-Fin 2020. http://www.eapn.fi/wpcontent/uploads/2020/10/EAPN-FIN-PowertyWatch-Poverty-Watch-ReportFinland-2020.pdf

Greve, B., Blomquist, P., Hvinden, B. \& van Gerven, M. (2020). Nordic welfare states-still standing or changed by the COVID-19 crisis? Social Policy Administration, 2020(55), 295-311. https://doi.org/10.1111/spol.12675

Haikkola, L. \& Kauppinen, E. (2020). Nuorten korona-ajan yksinäisyys ja näkemykset koronan vaikutuksista tulevaisuuteen. Poikkeusolot - nuorten arki koronan keskellä -kirjoitussarja. Helsinki: Nuorisotutkimusseura. https://www.nuorisotutkimusseura.fi/nakokulma66

Harrikari, T., Romakkaniemi, M., Tiitinen, L. \& Ovaskainen, S. (2021). Pandemic and Social Work: Exploring Finnish Social Workers' Experiences through a SWOT Analysis. The British Journal of Social Work, 51(5), 1-19. https://doi.org/10.1093/bjsw/bcab052

Healy, K. (2001). Reinventing Critical Social Work: Challenges from Practice, Context and Postmodernism. Critical Social Work 2(1). https://ojs.uwindsor.ca/index.php/csw/article/view/5618 Helliwell, J. F., Layard, R., Sachs, J. \& De Neve, J. E. (Eds.). (2021). World Happiness Report 2021. Sustainable Development Solutions Network. Holte, B. H., Swart, I. \& Hiilamo, H. (2019). The NEET concept in comparative youth research: The Nordic countries and South Africa. Journal of Youth Studies, 22(2), 256-272. https://doi.org/10.1080/13676261.2018.1496406 Jamaluddin, S. Z., Wah, F. Y. \& Taher, M. A. (2021). Covid-19: A preliminary assessment on the social security framework for an aged Malaysia. 
Commonwealth Law Bulletin, 47(1), 55-71.

https://doi.org/10.1080/03050718.2020.1834421

Jokela, M., Jauhiainen, S., Korpela, T. \& Tuori, S. (forthcoming). The impact of the COVID-19 pandemic on employment and the receipt of social benefits in Finland. Zeitschrift für Sozialforschung.

Kangas, O. (2020). Finland: Policy measures in response to the COVID-19 pandemic. ESPN Flash Report 2020/59.

https://ec.europa.eu/social/main.jsp?advSearchKey=ESPNFlash\&mode=advan cedSubmit\&catld $=22 \&$ policyArea $=0$ \&policyAreaSub $=0 \&$ country $=0$ \&year $=0$

Karjalainen, P. (2016). Sosiaalityön uusi asento: paikka, rooli ja orientaatio. In S.

Blomgren, J. Karjalainen, P. Karjalainen, M. Kivipelto, P. Saikkonen, \& P.

Saikku. (Eds.), Sosiaalityö, palvelut ja etuudet muutoksessa. Raportti 4/2016 (p. 119-136). Terveyden ja hyvinvoinnin laitos.

https://www.julkari.fi/handle/10024/130515

Karjalainen, P., Metteri, A. \& Strömberg-Jakka, M. (2019). ROADMAP. Report on the future of social work with adults. Reports and Memorandums of the Ministry of Social Affairs and Health 2019:41. Ministry of Social Affairs and Health. http://urn.fi/URN:ISBN

Kestilä, L., Jokela, M., Härmä, V. \& Rissanen, P. (Ed.). (2021). Effects of the COVID19 epidemic on well-being, the service system, and the national economy: Expert evaluation, Spring 2021. THL Report 3/. The Finnish Institute for Health and Welfare.

Kivipelto, M. \& Koponen E. (2021) Osallistavan sosiaaliturvan mallin vaikuttavuus. In A.-L. Matthies, A.-R. Svenlin, \& K. Turtiainen (Eds), Aikuissosiaalityö. Tieto, käytäntö ja vaikuttavuus (p. 233-249). Gaudeamus

Kivipelto, M., Blomgren, S., Karjalainen, P. \& Saikkonen, P. (Eds.). (2013).

Vaikuttavaa aikuissosiaalityötä - arviointimalleista mittareihin. Tutkimus- ja kehittämishankkeen loppuraportti, Raportteja 8. Finnish Institute for Health and Welfare.

Kuuskoski, R. (2020). "Voin kertoa miten paljon ärsyttää ruokaohjelmat": ulkopuolisuus Nälkä-kirjoituskilpailun teksteissä. Master's thesis. University of Jyväskylä. http://urn.fi/URN:NBN:fi:jyu-202003312609 
Laihiala, T. \& Nick, R. (2020). Koronakriisin vaikutuksen ruoka-apuun keväällä 2020. Ruoka-apu.fi. https://ruoka-apu.fi/wp-content/uploads/2020/09/Koronakriisinvaikutukset-ruoka-apuun_Laihiala-ja-Nick-2020-1.pdf

Lavalette, M., loakimidis, V. \& Ferguson, I. (2020). Conclusion: No return to 'business as usual'. In M. Lavalette, V. Ioakimidis, \& I. Ferguson (Ed.), Social Work and the COVID-19 Pandemic International Insights. Policy Press. https://doi.org/10.2307/j.ctv1850gc4.26

Linnavirta, S., Kroll, C, \& Blomberg, H. (2020). Ruoka-avun saajien näkemykset toimeentulotukiuudistuksesta. In T. Korpela, H-M Heinonen, M. Laatu, S. Raittila \& M. Ylikännö (Ed.), Ojista allikkoon? Toimeentulotukiuudistuksen ensi metrit (p. 152-185). Teemakirja 18. Kela.

Lipsky, M. (2010). Street-Level Bureaucracy. Dilemmas of the Individual in Public Services. 30th anniversary expanded edition. Russell Sage Foundation. Marjanen, P., Spolander, G. \& Aulanko, T. (2018). Neoliberalism, welfare state and social work practice in Finland. In M. Kamali, J. H. Jönsson (Eds), Neoliberalism, Nordic Welfare States and Social Work: Current and Future Challenges. Routledge.

Martin, A., Markhvida, M., Hallegatte, S. \& Walsh, B. (2020). Socio-Economic Impacts of COVID-19 on Household Consumption and Poverty. Economics of Disasters and Climate Change, 2020(4), 453-479. https://doi.org/10.1007/s41885-020-00070-3

Ministry of Social Affairs and Health (2020a). Guidelines for Corona. https://stm.fi/en/guidelines-for-the-prevention-of-coronavirus Ministry of Social Affairs and Health (2020b). Preparedness for the COVID-19 disease. https://stm.fi/en/coronavirus-preparedness

Mishna, F., Milne, E., Bogo, M. \& Pereira, L. F. (2020). Responding to COVID-19: New Trends in Social Workers' Use of Information and Communication Technology. Clinical Social Work Journal, 49, 484-494. https://doi.org/10.1007/s10615-020-00780-x

Mäntysaari, M. \& Ylistö, S. (2021). Työllistymistä edistävän monialaisen palvelun vaikuttavuus. In A.-L Matthies, A.-R. Svenlin \& K. Turtiainen (Ed.), Aikuissosiaalityö. Tieto, käytäntö ja vaikuttavuus (p. 250-266). Gaudeamus. Napier, D. (2020). Rethinking vulnerability through Covid-19. Anthropology Today, 36(3), 1-2. https://doi.org/10.1111/1467-8322.12571 
Nelimarkka, S., Maijala, S., Eriksson, P. \& Heino, T. (2021). Koronapandemian vaikutuksia lastensuojelun palveluihin ja asiakkaiden hyvinvointiin vuonna 2020. Työpaperi 5/2021. Helsinki: Terveyden ja hyvinvoinnin laitos. http://urn.fi/URN:ISBN:978-952-343-623-7

Pettinicchio, D., Maroto, M., Chai, L. \& Lukk, M. (2021). Findings from an online survey on the mental health effects of COVID-19 on Canadians with disabilities and chronic health conditions. Disability and Health Journal, 14(3). https://doi.org/10.1016/j.dhjo.2021.101085

Ohisalo, M. \& Saari, J. (2014). Kuka seisoo leipäjonossa? Ruoka-apu 2010-luvun Suomessa. Kunnallisalan kehittämissäätiö.

Oreffice, S. \& Quintana-Domeque, C. (2020). Gender Inequality in Covid-19 Times: Evidence from UK Prolific Participants. IZA Discussion Paper No. 13463. https://doi.org/10.2139/ssrn.3648803

Patel, J. A., Nielsen, F., Badiani, A. A., Assi, S., Unadkat, V. A., Patel, B., Ravindrane, R. \& Wardle, H. (2020). Poverty, inequality and COVID-19: The forgotten vulnerable. Public Health, 2020(183), 110-111. https://doi.org/10.1016/j.puhe.2020.05.006

Platt, L. \& Warwick, R. (2020). Are some ethnic groups more vulnerable to COVID-19 than others?. The Institute for Fiscal Studies, Nuffield Foundation. http://www.ifs.org.uk/inequality/wp-content/uploads/2020/04/Are-some-ethnicgroups-more-vulnerable-to-COVID-19-than-others-V2-IFS-Briefing-Note.pdf Power, K. (2020). The COVID-19 pandemic has increased the care burden of women and families. Sustainability: Science, Practice and Policy, 16(1), 67-73. https://doi.org/10.1080/15487733.2020.1776561

Prime Minister's Office (2020). PMO's Corona Management was Strengthened. https://valtioneuvosto.fi/en/-/10616/valtioneuvoston-koronajohtamista-vahvistett iin

Salin M, Kaittila A, Hakovirta M, \& Anttila M. (2020). Family Coping Strategies during Finland's COVID-19 Lockdown. Sustainability 12(21), 9133. https://doi.org/10.3390/su12219133

Sen, A. (2001). Development as Freedom. Oxford University Press.

Social Insurance Institution of Finland (2020a). Unemployment benefit in the coronavirus situation. https://www.kela.fi/web/en/unemployment-benefit-corona 
Social Insurance Institution of Finland (2020b). Two temporary benefits available from Kela amid the coronavirus outbreak. https://www.kela.fi/web/en/pressreleases-about-the-coronavirus-situation//asset_publisher/u3rOjDyugFv4/content/two-temporary-benefits-available-fromkela-amid-the-coronavirus-outbreak

Social Insurance Institution of Finland (2020c). Social assistance in the coronavirus situation. https://www.kela.fi/web/en/social-assistance-in-the-coronavirussituation

Suvisaari, J., Kärkkäinen, J. \&Vorma, H. (2021). Koronaepidemialla vaikutuksia psykiatriseen erikoissairaanhoitoon, mutta vaikutuksissa alueellisia eroja. In Koronaepidemian vaikutukset hyvinvointiin, palveluihin ja talouteen. THL:n seurantaraportti, viikot 2-3/2021, 27.1.2021, 17-18.

THL, Avohilmo (2021). Perusterveydenhuollon käynnit ja käyntisyyt. Terveyden ja hyvinvoinnin laitos. https://thl.fi/fi/tilastot-ja-data/ohjeet-tietojentoimittamiseen/perusterveydenhuollon-avohoidon-hoitoilmoitus-avohilmo/raportit Tiirinki, H., Tynkkynen, L. K., Sovala, M., Atkins, S., Koivusalo, M., Rautiainen, P., Jormanainen, V. \& Keskimäki, I. (2020). COVID-19 pandemic in Finland Preliminary analysis on health system response and economic consequences. Health Policy and Technology, 9(4), 649-662. https://doi.org/10.1016/j.hlpt.2020.08.005

Tiitinen, L., Ovaskainen, S., Harrikari, T. \& Romakkaniemi, M. (2020). COVID-19 and social work: A collection of country reports: Finland. In L. Dominelli, T. Harrikari, J. Mooney, V. Leskošek \& E. Kennedy Tsunoda (Ed.), COVID-19 and Social Work: A Collection of Country Reports (p. 40-44). The International Association of Schools of Social Work. https://www.iassw-aiets.org/wpcontent/uploads/2020/07/IASSW-COVID-19-and-Social-Work-Country-ReportsFinal-1.pdf

Tuikka, A. M. (2019). Evaluating Digitalization of Social Services from the Viewpoint of the Citizen. In I. O. Pappas, P. Mikalef, Y. K. Dwivedi, L. Jaccheri, J. Krogstie \& M. Mäntymäki (Ed.), Digital Transformation for a Sustainable Society in the $21^{\text {st }}$ Century (p. 23-30). Springer.

Tuominen, T. (2021) Arjen toimijuus aikuissosiaalityön nuorilla miesasiakkailla. In A.L. Matthies, A.-R. Svenlin \& K. Turtiainen (Eds.), Aikuissosiaalityö. Tieto, käytäntö ja vaikuttavuus (pp. 101-117). Gaudeamus. 
Van Winkle, B., Carpenter, N., \& Moscucci, M. (2017). Why Aren't Our Digital Solutions Working for Everyone? AMA Journal of Ethics, 19(11), 1116-1124. https://doi.org/10.1001/journalofethics.2017.19.11.stas2-1711 